\title{
O ARREPENDIMENTO DE PERCEVAL: RELAÇÕES ENTRE A FORMA, O SENTIDO E A HISTÓRIA NO CONTO DO GRAAL DE CHRÉTIEN DE TROYES (C. 1180-1191)'
}

Contato

Av. Efigênio Salles, 2000 - Bloco Renoir - Apto. 301 69060-020 - Manaus - Amazonas - Brasil sinvalcmg@gmail.com
- Sínval Carlos Mello Gonçalves²

Universidade Federal do Amazonas

Amazonas - Manaus - Brasil

\section{Resumo}

A partir de um episódio do Conto do Graal, de Chrétien de Troyes, são analisados alguns elementos formais dessa narrativa, sobretudo, aqueles relacionados com os encadeamentos dos episódios e com as motivações de seu protagonista, tentando colocar em evidência a lógica de seu funcionamento. Para que se deixe mais evidente essa lógica, é feita uma comparação com dois episódios de O crime e castigo, do romancista russo Fiódor Dostoiévski. Os sentidos propostos a partir dessa análise são, enfim, situados em seu contexto mais amplo e relacionados, em particular, com o estatuto da pessoa no Ocidente medieval.

\section{Palavras-chave}

Narrativa - Idade Média - Chrétien de Troyes - Graal - Noção de pessoa.

${ }^{1}$ Artigo não publicado em plataforma preprint. Todas as fontes e bibliografia utilizadas são referenciadas no artigo

2 Doutor em História Medieval pela Universidade Federal Fluminense (UFF), Professor Titular do Departamento de História da Universidade Federal do Amazonas (UFAM). 
REPENTANCE:

RELATIONSHIPS

BETWEEN FORM,

MEANING AND

HISTORY IN THE GRAIL'S

TALE BY CHRÉTIEN DE

\section{TROYES}

Contato

Av. Efigênio Salles, 2000 - Bloco Renoir - Apto. 301 69060-020 - Manaus - Amazonas - Brasil sinvalcmg@gmail.com

\section{- Sínval Carlos Mello Gonçalves}

Universidade Federal do Amazonas

Amazonas - Manaus - Brazil

\section{Abstract}

Based on an episode of the Grail's Tale, by Chrétien de Troyes, some formal elements of this narrative are analyzed, especially those related to the chaining of the episodes and the motivations of its protagonist, trying to highlight the logic of its functioning. In order to make this logic more evident, a comparison is made with two episodes of The Crime and Punishment, by the Russian novelist Fiódor Dostoiévski. The meanings proposed from this analysis are, finally, situated in their broader context and related, in particular, to the status of the person in the medieval West.

\section{Keywords}

Narrative - Middle Ages - Chrétien de Troyes - Grail - Notion of person. 


\section{1 - O problema: a motivação desconhecida}

O último episódio protagonizado por Perceval, no inacabado romance de Chrétien de Troyes acerca do Graal'3, tem como eixo central sua confissão a um eremita, que decidira procurar após o encontro com um grupo de penitentes na Sexta-Feira Santa.

Estes, depois de o repreenderem por estar armado no dia da morte de Cristo, relataram-lhe seu encontro com aquele eremita, a quem tinham feito sua própria confissão. A repreensão feita pelos penitentes, reforçada pela exposição de como Cristo sacrificara-se para purificar a humanidade por seus pecados, ao assumir uma forma corporal e nela sofrer as penas da crucificação, despertou em Perceval, que já se encontrava num estado de extrema aflição, a necessidade de buscar o eremita para confessar o que ele, inicialmente, irá expressar como a causa de seu sofrimento: o "esquecimento de Deus" durante os cinco anos anteriores ${ }^{4}$, todos eles consumidos em aventuras "duras, estranhas e perigosas", como nos informa o narrador de sua história (TROYES, 1994, p. 838, v. 6227-6228).

O episódio da confissão de Perceval estender-se-á ao longo de quase quatrocentos versos e, além de assinalar o momento em que ele se torna plenamente consciente de seu estado ${ }^{5}$, esclarecerá o significado de alguns elementos e personagens do acontecimento que o levara até aquela condição: sua passagem pelo castelo de um rei enfermo, onde presenciara um estranho e enigmático cortejo, diante do qual silenciara, a despeito de sua curiosidade acerca do que ele poderia significar.

\footnotetext{
3 O romance de Chrétien de Troyes acerca do Graal foi composto, muito provavelmente, entre os anos de 1180 e 1191. Seu título, "O conto do Graal", é mencionado no prólogo do romance: "Ce est li contes del graal" "“Este é o conto do graal); (TROYES, 1994, p. 686, v. 86). Alternativamente, as diversas edições modernas do romance utilizam, para designá-lo, o nome de seu protagonista, Perceval. Quando assim o fizer, o nome do personagem será escrito em itálico. Todas as citações do romance serão feitas a partir desta edição, preparada por Daniel Poirion para a Bibliothèque de la Plèiade. As traduções dos versos foram feitas por mim.

4 "Percevax, ce conte l'estoire,/A si perdue la memoire/ Que de Deu ne li sovient mais." ("Perceval, assim diz a história,/ Perdeu de tal forma a memória/ Que de Deus não se lembra mais.) (TROYES, 1994, p. 838, v. 6217-6219).

${ }^{5}$ A expressão "plenamente consciente de sua situação" não deve ser tomada, evidentemente, como uma avaliação objetiva e exterior ao texto, afinal, alguns de seus referenciais essenciais, sobretudo, aquele relativo ao "pecado" de Perceval, só podem ser tomados como absolutos no interior do sistema de valores e de crenças em que a narrativa está inserida.
} 
Este episódio será, enfim, o último protagonizado por Perceval no interior da narrativa de Chrétien de Troyes, e seu momento decisivo é, certamente, aquele em que lhe foi revelado seu pecado mais grave, até então desconhecido por ele mesmo: o abandono da mãe por ocasião de sua partida para tornar-se cavaleiro. Seria este pecado o verdadeiro responsável, segundo o eremita, pelo seu silêncio diante do cortejo do Graal, fato julgado pelo jovem cavaleiro, então, como o único e principal responsável por sua aflição.

Nessa confissão, porém, em que pese o estado de profunda consternação e abandono de nosso protagonista, há um detalhe que, se talvez fosse exagerado considerar como deliberada impostura, não seria certamente incorreto tratar como imprecisão ou, pelo menos, como voluntária ou involuntária ambiguidade: refiro-me, aqui, ao verso em que Perceval afirma ter sofrido profunda aflição depois (puis, v. 6381) de seu silêncio a respeito dos enigmáticos eventos presenciados junto ao "rei Pescador", formulação que poderia ser interpretada, por quem não conhecesse sua história - e este era o caso do eremita - como imediatamente após aquele momento, confundindo-se assim o momento da suposta falta com o de sua tomada de consciência. ${ }^{6}$

Na realidade, e mesmo que não se considere nenhuma das duas possibilidades de leituras sugeridas acima, se retornarmos aos eventos daquela noite e aos que imediatamente a seguiram, atestaremos um sugestivo lapso de tempo entre o instante da suposta falta e o de sua tomada de consciência. E, mais do que isso, atestaremos que a consciência atormentada de Perceval não virá do silêncio em si, mas do significado atribuído a sua atitude por duas acusações, ambas enunciadas após a noite de seu jantar com o rei Pescador. A primeira delas, no dia seguinte, foi proferida logo após a sua saída do castelo, e a outra um pouco mais tarde, na noite em que se festejava sua integração à corte do rei Artur. No entanto, e este é o fato fundamental, sem que a narrativa, ou o seu narrador, expliquem as razões para isso, enquanto no primeiro momento a acusação não teve o menor efeito sobre o seu estado emocional, no segundo ela o colocou no estado de extrema

\footnotetext{
${ }_{6}$ Este é o verso integral em seu contexto: Et del Graal que ge i vi/Ge ne sai cui l'an servi,/ S'an ai puis eü si grant duel /Que morz eüsse esté mon vuel (E do Graal que lá eu vi/Eu não sei a quem ele servia,/Disso eu tive depois uma tão grande dor/Que desejaria agora estar morto) (TROYES, 1994, p. 842, v. 6379-6382). No caso do verso em questão deve-se mencionar que todos os manuscritos do Perceval mantêm a palavra puis (depois) para referir-se ao tempo da tomada de consciência da falta, com exceção do manuscrito C, que proporciona a variante or (agora). Todas as variantes do Perceval podem ser encontradas na admirável edição crítica de Keith Busby, a qual considerou todos os manuscritos conhecidos do romance (TROYES, 1993).
} 
aflição que o levaria, cinco anos mais tarde, ao encontro com o eremita. É preciso, portanto, analisar estas acusações para tentar descobrir as possíveis razões da aparente incongruência causada por essa omissão.

\section{2 - Os fatos: como interpretá-los?}

A primeira acusação ocorreu quando Perceval, cavalgando por uma trilha na floresta após ter deixado o castelo do rei Pescador, encontrou, à sombra de um carvalho, uma jovem chorando pela morte de um cavaleiro cujo corpo, sem a cabeça, amparava em seu colo. Numa atitude que nos parece surpreendente, diante do terror da cena, Perceval não demonstrará nenhum tipo de reação ou de empatia com relação à dor da jovem, perguntando-lhe apenas sobre quem havia matado o cavaleiro.

Logo em seguida, de maneira igualmente inusitada, a própria jovem pareceu esquecer sua dor, e mostrando-se surpresa por Perceval e seu cavalo estarem tão bem cuidados e descansados, perguntou de onde ele havia vindo. Ao saber que Perceval havia passado a noite no castelo do rei Pescador, a jovem, demonstrando um inexplicado e detalhado conhecimento acerca do que ocorrera na noite anterior, começou a interrogá-lo acerca de suas atitudes durante o jantar com aquele rei.

Nesta noite, de fato, Perceval havia presenciado uma série de acontecimentos enigmáticos e, aparentemente inexplicáveis, que suscitaram sua curiosidade, controlada em função do conselho de não falar em demasia, transmitido pelo personagem que o havia iniciado na cavalaria. Em função disso, ele se mantivera em silêncio, e nada perguntara quando um estranho cortejo passou várias vezes diante da mesa em que compartilhava uma rica refeição com o rei que o havia acolhido: na frente, um jovem portava uma lança de cuja ponta uma gota de sangue estendia-se até sua mão; ele era seguido por outro, que trazia um candelabro de ouro e, logo após este, por uma jovem que trazia um graal, também de ouro e ornado com inúmeras pedras preciosas, o qual irradiava uma luz de tal intensidade que todas as outras da sala ficavam por ela ofuscadas; por fim, outra jovem trazia consigo um cepo de prata. E durante toda a noite, como um contraponto aos pratos que eram servidos a Perceval e ao rei, o graal ia e vinha entrando e saindo de uma sala contígua àquela em que os dois desfrutavam de seu banquete. No dia seguinte, ao acordar disposto a interrogar acerca do significado da lança que sangrava sem parar, e sobre o que transportava e a quem se destinava aquele graal, não encontrou ninguém para responder às suas indagações, pois, o castelo parecia, agora, estar completamente desabitado. Ao entrar por 
uma trilha onde julgara terem entrado as pessoas do castelo ele terminou por encontrar, ao invés deles, a jovem com o cavaleiro morto em seu colo.

Depois de ouvir o relato de Perceval a respeito de sua noite no castelo, esta jovem, que logo em seguida saberemos ser sua prima, o acusará duramente por não ter perguntado sobre a razão do sangue na lança e a respeito de quem era servido pelo graal. Sua ira devia-se ao fato de que, segundo ela, caso Perceval houvesse feito estas perguntas o rei teria sido curado da enfermidade que o afligia, causada por um dardo lançado entre suas pernas durante uma batalha, ferimento que lhe ocasionara a perda de controle sobre seus membros inferiores e sobre o seu reino. A falha de Perceval seria, portanto, a causa da infelicidade que se abateria sobre ele e sobre os demais. Ela dirá, ainda, que o erro de Perceval devia-se ao pecado cometido por ele contra sua mãe, que morreu de desgosto após sua partida.

As acusações da jovem não tiveram, porém, o menor impacto sobre o nosso protagonista. A não ser a notícia da morte de sua mãe, mesmo assim logo superada por sua ânsia em partir, nada do que a menina falou sobre o erro cometido diante do Graal o abalou. ${ }^{7}$

A segunda acusação feita ao silêncio de Perceval leva-nos ao ponto de partida dos cinco anos de aventuras que antecederam seu encontro com o eremita, para a noite de uma grande festa destinada à celebração de sua integração à corte de Artur, fato desde muito tempo esperado em função das notícias de suas proezas de cavalaria, sempre concluídas pelo envio dos cavaleiros derrotados à corte daquele rei.

A celebração foi interrompida, porém, pela irrupção de uma jovem cujas fealdade e deformidades inauditas serão descritas pelo narrador de maneira bem detalhada. Depois de cumprimentar a todos da corte, com a exceção de Perceval, ela dirigiu-se a ele de maneira duríssima, acusando-o pelas mesmas razões antes apontadas por sua prima, ou seja, por ele não ter perguntado ao rei Pescador porque a lança sangrava e a quem era servido o graal, repetindo, então, o que ela havia dito acerca das consequências do silêncio de Perceval: a continuidade da enfermidade do rei Pescador e, por causa dela, a continuidade da anomia de seu reino, assim como a violência, a desolação e o caos dela decorrentes.

\footnotetext{
7 Recordemos que o eremita, ao falar do mesmo pecado para Perceval, dirá que este o desconhecia, o que parece francamente contraditório com esta passagem. A não ser que consideremos as palavras do eremita como uma confirmação a mais do absoluto desprezo, por parte de Perceval, desta primeira acusação.
} 
Dessa vez, porém, a acusação teve um impacto dilacerador sobre nosso protagonista: tomado pela culpa, ele decidiu partir no mesmo instante, com a intenção de não interromper jamais sua busca, até conseguir encontrar novamente o castelo do graal e fazer as perguntas não feitas por ocasião de sua estadia anterior. ${ }^{8}$ Como explicar, então, estas reações distintas diante de acusações tão semelhantes?

Uma possível explicação para as reações distintas de Perceval foi dada por Jean Frappier (1957), ainda que estas não se lhe apresentassem como problema, o que é compreensível em função de sua perspectiva de leitura, como logo veremos. Para ele, o impacto da segunda acusação, a da "jovem disforme", viria da menção explícita ao fato de que o rei jamais seria curado de sua enfermidade, e, portanto, jamais recuperaria seu reino, informação ausente naquela feita pela prima do protagonista. Frappier, no entanto, desconsidera o fato de que as consequências conjugadas do silêncio de Perceval - para o rei e para o reino - ao terem sido igualmente mencionadas pela prima, e de maneira bastante assertiva, já as deixavam implícitas, ainda que condensadas numa única palavra. ${ }^{9}$ Por outro lado, e este me parece o ele-

\footnotetext{
8 Para acentuar a diferença da reação de Perceval nos dois momentos, seria interessante notar que ele ainda proporá à sua prima, antes de continuar seu caminho, que ela deixe de lamentar pela morte de seu amante e siga em frente com ele. Que ela, enfim, deixe "os mortos aos mortos e os vivos aos vivos" ("Les morz as morz, les vis as vis.") (TROYES, 1994, p. 775, v. 3630). A sentença torna-se ainda mais significativa, creio eu, ao sabermos que ela foi dita por ele quase imediatamente após a revelação de que sua mãe já estava morta. Novamente, então, perguntemos, porque não veio naquele momento o imperioso desejo de Perceval reparar o erro cometido?

"Eis os versos em seu contexto, os da prima e, em seguida, os da "jovem disforme": "Ha! Percevax maleüreus,/Com fus or mesavantureus,/Qant tu tot ce n'as demandé,/Que tant eüsses demandé,/Le boen roi qui est maheigneiez/Que toz eüst regaaigniez/Ses manbres et terre tenist./Ensi granz biens en avenist!/Mes or sachez bien que enui/En avandra toi et autrui." ("Ah! Infeliz Perceval,/Como foste malaventurado,/Quando nada perguntaste,/Pois terias curado/O bom rei, que está enfermo./Ele recuperaria o controle/De seus membros e o domínio de sua terra./Disso viriam muitas coisas boas!/Mas agora saiba que sofrimentos/Virão, para ti e para os outros." (v. 3583-3592); “(...) se tu demandé eüsses,/Li riches rois qui si s'esmaie/ Fust ores gariz de sa plaie/Et si tenist sa terre an pes,/Dom il ne tanra point ja mes./Et sez tu qu'il avandra/Del roi qui terre ne tandra/Ne n'iert de sa plaie gariz?/Dames an perdront lor mariz,/Terres an seront essilliees/Et puceles desconselliees/Qui orfelines remandront,/Et maint chevalier an morront,/Et tui avront le mal par toi." "(...) se tivesses perguntado,/O rico rei, que está tão fraco/Teria sido curado de sua ferida/E assim dominado em paz sua terra,/Sobre a qual jamais terá domínio./E sabes o que acontecerá/Por causa do rei que não terá sua terra/
} 
mento essencial, sua leitura baseia-se numa interpretação das motivações interiores da partida de Perceval e, sobretudo, do pressuposto de que estas guardariam estreitas semelhanças com as suas: a partida do jovem cavaleiro seria, assim, fruto de sua "recusa da fatalidade" e Perceval seria "um heroi da liberdade interior" (FRAPPIER, 1957, p. 182), interpretação que negligencia e despreza o silêncio absoluto da narrativa acerca da subjetividade de seu protagonista $^{10}$. E que, sobretudo, pressupõe que esta obedeça à lógica e aos valores do intérprete moderno.

Mas poderíamos argumentar, ainda, que os impactos distintos dos dois discursos sobre Perceval poderiam ser explicados pelos contextos distintos, e obviamente, pelas diferenças entre quem os proferiu.

Examinemos, portanto, estes dois contextos e os seus respectivos personagens, com o objetivo de saber se eles poderiam explicar as diferentes reações de Perceval: enquanto as acusações da prima foram proferidas sem a presença de testemunhas, no silêncio dos bosques, as da "jovem disforme" foram ditas em plena corte de Artur, justamente após os três dias de celebração dedicados à integração de Perceval ao corpo de cavaleiros do rei. $\mathrm{O}$ próprio rei não escondia a satisfação de poder, enfim, redimir-se do erro de não ter conseguido estimar claramente, por ocasião de seu primeiro encontro com o então inexperiente e rústico jovem, o brilhante futuro a que ele estava destinado. Depois, a própria personagem que proferiu as acusações, dotada de uma aparência física grotesca, a qual é descrita com muitos detalhes, contrastando com a inexistência de quaisquer menções desta natureza com relação à prima de Perceval. A estes dois elementos conjugados, ou seja, a humilhação pública e a força emanada pela jovem - força de que seu aspecto físico seria a face visível - poder-se-ia atribuir a intensidade da como-

\footnotetext{
Nem será de sua ferida curado?/Mulheres perderão seus maridos,/As terras serão devastadas,/ As jovens desamparadas,/Pois ficarão órfãs,/E muitos cavaleiros irão morrer./E todos sofrerão por tua causa." (v. 4670-4683). Note-se que Frappier utiliza, em seu estudo, a edição de Alfons Hilka, baseada no mesmo manuscrito utilizado como base por Daniel Poirion, o BNfr. 794.

${ }^{10}$ Em sua avaliação geral da narrativa, o próprio Frappier reconhece os vazios deixados pelo narrador, fato que me parece bastante significativo: "La conduite du récit n'est pas toujours d'une clarté parfaite, car le conte merveilleux comportait une part de mystère, et Chrétien a gardé, à bon escient, beaucoup de cette étrangeté. Elle devait l'amuser, le seduire aussi: dejà dans ses oeuvres antérieures, surtout dans la Charrette, sa manière narrative emprutait à l'extraordinaire un usage adroit des explications suspendues ou même refusées; plus que jamais les énigmes et les ombres lui servent à piquer la curiosité et à retenir l'intérêt" (1957, p. 174). Aqui, no entanto, a estranheza da narração é atribuída ao teor da narrativa e não ao narrador, cuja forma de pensar parece-lhe mais próxima da sua do que da de seu objeto narrativo.
} 
ção de Perceval, e não aos conteúdos das acusações, na medida em que eles já haviam sido mencionados por sua prima, com o mesmo tom acusatório utilizado pela "donzela disforme"."1

Porém, mais do que identificar as possíveis distinções entre as duas circunstâncias e as duas personagens, para através delas tentar compreender as razões das reações de Perceval, o mais importante, aqui, é registrar o fato de que suas diferentes reações diante das duas acusações não são explicitadas e nem explicadas pelo narrador, que se limita a relatar o acontecido sem explicar as causas ou as razões de seu personagem. Desse modo, não deixa de ser tentador pensar que a hipótese esboçada no parágrafo anterior atenda a uma necessidade intelectual muito mais presente em nós, incomodados com o vazio deixado pelo narrador e pela consequente impressão de inconsistência narrativa, do que em seu auditório medieval. ${ }^{12}$

Mas, de onde viria o incômodo sentido pelo leitor moderno diante da inexistência de explicação para as reações distintas de Perceval, quando confrontado, em momentos diferentes, com as mesmas acusações? Creio que uma parte da resposta, pelo menos, resida em nossos hábitos mentais, fundamentalmente avessos à inexistência de um nexo claro e lógico entre os acontecimentos - sejam eles exteriores ou, como é o caso no Perceval, interiores - e os agentes causais que os orientam em uma ou em outra direção.

Para evidenciar o papel deste aspecto verdadeiramente constitutivo de nossos hábitos mentais, e assim, pelo contraste, deixar mais claro o que nos distancia e nos intriga na construção do texto medieval, talvez seja interessante fazer uma incursão nos tempos modernos com o fim de encontrar, em seu termo, um romance onde as ideias complementares de culpa e redenção, apesar de fazerem eco a um dos temas centrais do Perceval, não nos permitem deixar de perceber tudo aquilo que nos distancia, e que nos fazem pressentir o quão longe estamos daqueles séculos, em que pese esta coincidência

\footnotetext{
${ }^{11}$ Outra possibilidade de explicação seria identificar algum tipo de alteração no estado psicológico de Perceval, supostamente ocorrida entre o tempo de uma e outra acusação, mas não há nada, nos fatos da narrativa, que nos permita afirmar isso de maneira definitiva.

${ }^{12}$ Esta inconsistência, pelo menos aparente, não aparece somente na falta de uma explicação plausível para a drástica alteração nos sentimentos do protagonista acerca de si mesmo, ela atravessa praticamente toda a narrativa e torna-se especialmente pronunciada através dos inúmeros personagens e lugares que aparecem e desaparecem sem que saibamos as razões para que isso aconteça, a exemplo da própria prima de Perceval, cujas causas para o conhecimento das coisas concernentes ao castelo do rei Pescador jamais serão explicitados pelo narrador. Não sabemos, igualmente, de onde veio a "jovem disforme", e tampouco saberemos quem ela é e de onde vem seu saber.
} 
temática e a consequente possibilidade de existir, entre os dois, algum tipo de continuidade histórica ${ }^{13}$.

Não nos esqueçamos, antes de fazer esta incursão, que estes mesmos hábitos mentais estão na base, por sua vez, dos princípios norteadores do romance moderno, os quais poderiam ser sintetizados pela noção de "verossimilhança", ou seja, pela necessária adequação da narrativa ao que se poderia chamar de "princípio de realidade" (WATT, 2010, p. 9-36).14

\section{3 - Uma incursão na modernidade: o "Crime e castigo" de Dostoiévski}

Publicado pela primeira vez em 1866, o justamente clássico e célebre romance do escritor russo Fiódor Dostoiévski, pode ser lido como a brilhante e iluminadora descrição analítica de uma consciência atormentada por impulsos terríveis e, pelo menos na situação concreta do personagem, incontornáveis.

Do mesmo modo que no Perceval, ainda que em circunstâncias narrativas distintas, a disjunção, pelo menos aparente, entre a motivação e as reações de seu personagem, pode ser observada em duas passagens decisivas para o protagonista do Crime e castigo. Neste romance, porém, essa disjunção é vista como algo inusitado e inquietante, justamente por manter-se alheia a qualquer tipo de explicação causal plausível e limitada aos fatos humanos, daí o interesse em sua análise.

A primeira destas passagens, situada ainda na parte inicial do relato, narra seu encontro com Marmieládov, um funcionário aposentado, a quem o alcoolismo e a miséria haviam reduzido a um estado lamentável. O conhe-

\footnotetext{
${ }^{15}$ Observemos que os anos de composição do Perceval de Chrétien de Troyes estão englobados por um arco temporal marcado pela ascensão da introspecção como elemento fundamental no sistema penitencial da sociedade medieval. Ascensão justamente vinculada ao arrependimento, agora concebido como um ato essencial para a purificação do pecador (BASCHET, 2006) e (DELUMEAU, 1991).

${ }^{14}$ Sobre o "princípio de realidade": "Na verdade, é justo dizer que durante grande parte do século $\mathrm{XX}$, os romancistas por toda a Europa e os Estados Unidos estavam firmemente comprometidos com o princípio de realidade. Fizeram, por assim dizer, um pacto tácito com o público leitor que os obrigava a permanecer fiéis às verdades sobre os indivíduos e sua sociedade, a inventar apenas pessoas e situações "reais", em suma, a ser dignos de confiança em suas ficções sobre a vida comum. As sagas românticas sobre cavaleiros galantes e aventuras improváveis, damas sedutoras e amantes condenados, tudo banhado num luxo extravagante, não eram para eles." (GAY, 2010, p. 11-12).
} 
cimento e a aproximação entre os dois personagens ocorrem num momento em que, segundo o narrador, Raskólnikov “(...) vinha evitando qualquer tipo de companhia" (DOSTOIÉVSKI, 2001, p. 28).

Perturbado, porém, pela força de como se insinuava em sua consciência o pensamento de assassinar uma velha usurária a quem recorria de maneira frequente, ele terminou por ceder ao impulso de entrar, pela primeira vez, numa taberna. E note-se, por fundamental, a observação do narrador a respeito das circunstâncias singulares do encontro, então prestes a ocorrer: "Agora, porém, alguma coisa o impelira de repente para o convívio humano." (DOSTOIÉVSKI, 2001, p. 28, grifos meus).

O caráter indeterminado dos motivos da inusitada ação de Raskólnikov, ao decidir entrar na taberna, irá somar-se à igualmente inexplicada impressão causada pelo funcionário em seu espírito, fato decisivo para a posterior aproximação. E a impossibilidade de explicar de maneira plausível a ação e a impressão de Raskólnikov, torna-se ainda mais significativa, para a compreensão da construção do relato, pela importância deste encontro para o destino do protagonista, pois, através de Marmieládov ele irá conhecer sua filha Sônia, que irá não apenas acompanhar seu tormento após o assassinato, como também terá um papel essencial em sua redenção final.

É a partir dessa conjunção entre a indeterminação causal dos impulsos de Raskólnikov e a importância das consequências que eles terão em sua vida futura, que precisaremos ler as sentenças seguintes, e notar como esses fatos inexplicáveis fluem e formam um elo, de uma oração a outra, entre a consciência do narrador e a de seu personagem:

Acontecem certos encontros com pessoas que desconhecemos inteiramente, por quem começamos a nos interessar a primeira vista, como que de repente, súbito, antes que articulemos uma palavra. Foi exatamente essa a impressão que produziu em Raskólnikov o visitante que estava sentado a distância e parecia um funcionário público aposentado. Mais tarde o jovem recordaria várias vezes essa primeira impressão e chegaria a atribuí-la a um pressentimento. (DOSTOIÉVSKI, 2001, p. 28, grifo meu).

$$
* * *
$$

A segunda passagem significativa para nossos propósitos remete às circunstâncias em que o ato de assassinar a velha usurária, até então sujeito às idas e vindas do humor instável e turbulento de Raskolnikóv, tornou-se um imperativo absolutamente inevitável em sua consciência. 
Novamente, um encontro fortuito e casual será o seu eixo fundamental. E para realçar o mistério de sua indeterminação, ele ocorrerá justamente num momento em que o nosso protagonista desistira de seu intento, certamente motivado por um pesadelo em que revivera um fato marcante de sua infância: o abate cruel e a sangue frio de um pangaré por um bando de bêbados, presenciado por ele e por seu pai ao passarem diante de uma taberna situada no caminho da igreja onde costumavam assistir às missas. O efeito do sentimento infantil revivido pelo sonho fizera-lhe sentir, então, como lhe seria insuportável o ato de assassinar a velha agiota.

No caminho de volta para casa, porém, um inexplicado impulso o fez tomar um caminho inusual e passar por uma praça onde terá o encontro, definitivo e decisivo para seu destino, com Lisavieta Ivánovna, a irmã caçula com quem a velha usurária dividia seu apartamento. Uma conversação entre ela e um dos muitos vendedores ambulantes da praça, ouvida fortuitamente, o faz saber que no dia seguinte, em determinada hora, a moça não estaria em casa, informação assumida como uma espécie de revelação de seu destino, agora tornado inelutável, de cometer o crime. A narrativa, uma vez mais, não esconde a surpresa e a estranheza tanto pela ação inexplicável do protagonista, como pelas consequências determinantes que ela terá em seu destino:

Não havia meio de entender e explicar para si mesmo por que ele, cansado, atribulado, voltou para casa pela praça Siénnaia, por onde lhe seria dispensável passar, já que era muito mais vantajoso retornar pelo caminho mais curto e direto. (...) Mas porque, sempre se perguntava, por que aquele encontro na Siénnaia (por onde ele não tinha nenhuma necessidade de passar), tão importante, tão decisivo para ele e ao mesmo tempo tão sumamente casual, coincidia agora com essa hora, com esse minuto de sua vida, justamente com esse seu estado de ânimo e precisamente com essas circunstâncias em que só ele, o tal encontro, poderia produzir o efeito mais decisivo e definitivo em todo seu destino? Como se ali estivesse de propósito à sua espera! (DOSTOIÉVSKI, 2001, p. 76, grifos meus.).

Numa passagem imediatamente anterior o narrador, novamente transferindo para o personagem uma incompreensão jamais resolvida pela narrativa, assinala a intensidade obsessiva com que Raskólnikov irá rememorar, na impossibilidade de explicar, aquele encontro decisivo. E não se poderá deixar de observar, ao ler suas palavras, as relações entre os termos "pressentimento" - utilizado por ocasião do encontro com Marmieládov - e "predefinição" - este agora utilizado igualmente pelo personagem para definir o caráter de seu encontro com Lisavieta. Ambos significativamente remetendo a uma espécie de predestinação que não poderia ter outro qualificativo, no contexto cultural da narrativa, a não ser o de "superstição": 
Mais tarde, quando rememorava esse período e tudo que lhe aconteceu nesses dias, minuto a minuto, ponto por ponto, traço por traço, sempre o invadia uma perplexidade que chegava à superstição, devido a uma circunstância que, no fundo, embora não fosse muito incomum, depois lhe pareceu constantemente uma espécie de predefinição do seu destino. (DOSTOIÉVSKI, 2001, p. 75, grifos meus).

Perplexidade tanto mais compreensiva pelos efeitos poderosos do encontro sobre sua consciência, desde então dominada por um impulso que literalmente se apoderou de sua vontade:

Faltavam alguns passos para chegar ao seu apartamento. Ele entrou como um condenado à morte. Não raciocinava sobre nada e absolutamente sobre nada podia raciocinar; mas de repente sentiu em todo o seu ser que não tinha mais liberdade de juízo, nem vontade, e que subitamente tudo tinha sido resolvido em definitivo. (DOSTOIÉVSKI, 2001, p. 77, grifos meus).

O leitor certamente observou as similaridades e diferenças entre as duas séries de passagens analisadas, as do Perceval e as do Crime e Castigo. No romance de Chrétien de Troyes vimos um acontecimento similar produzir reações distintas no personagem, enquanto no de Dostoiévski, examinamos certas ações de seu protagonista, cujos impulsos não puderam ser determinados. Nos dois casos, porém, há um mesmo aspecto em causa, o das motivações de seus personagens. A distinção fundamental entre as duas séries de acontecimentos reside, justamente, no tratamento concedido a este aspecto pelos dois narradores: para o narrador moderno, ao contrário do medieval, a indeterminação dos motivos da ação é um problema essencial, e não há como ignorar este fato fundamental, sob o risco de invalidar a verossimilhança de seu personagem. É precisamente a partir deste imperativo, ainda essencial em nossos hábitos mentais, que a ausência de explicação do narrador medieval aparece-nos como um vazio, como uma falta.

A verificação dos diferentes tratamentos dados à motivação dos personagens, nas duas narrativas, permite-nos estabelecer esta diferença em outros termos, o das relações entre o nível da narração e o da história narrada, reiterando assim a relação direta entre as formas narrativas e os hábitos mentais. Desse modo, se no romance de Dostoiévski há uma evidente disjunção entre a natureza da história que está sendo relatada - dominada pelo feixe de razões mais ou menos indeterminadas de seu personagem - e o nível da narrativa -, fundamentado precisamente sobre a necessidade de compreendê-las, no de Chrétien de Troyes, ao contrário, a ausência de qual- 
quer surpresa do narrador diante das reações aparentemente inexplicáveis de seu personagem, parece revelar uma espécie de adesão entre os dois níveis de sua expressão, o da história e o de seu relato.

Mas esta breve incursão por um romance realista russo do século XIX, terminou por nos fazer observar, ainda, como o problema da indeterminação das motivações torna-se especialmente agudo quando as ações desencadeadas por elas assumem um caráter determinante para o destino de seus personagens. Daí o caráter obsessivo da ruminação posterior de Raskólnikov - que certamente reflete a de seu narrador e a de seu leitor -, todos perplexos com a constatação de como decisões inexplicáveis, e aparentemente fortuitas, conduziram-no a encontros tão fundamentais para sua vida futura.

Descobrir na história de Raskólnikov essa estranha e, nos termos de seu contexto narrativo, misteriosa conjunção entre atos desprovidos de uma intenção claramente determinada e acontecimentos decisivos para seu destino, deverá nos conduzir, de maneira talvez inesperada, de volta ao romance medieval, pois também veremos, na história de Perceval, a função decisiva daquilo que costumamos chamar de coincidências ou de acasos. No romance de Chrétien, porém, estas não serão resultado de um ato cuja motivação não é possível de ser determinada por seu agente, mas de uma disjunção entre a intenção, o ato e suas consequências. Mas aqui, uma vez mais, veremos despontar a dessemelhança essencial entre as duas: a absoluta indiferença do narrador medieval com relação a esses acasos. ${ }^{15}$

\footnotetext{
15 “O enredo do romance também se distingue da maior parte da ficção anterior por utilizar a experiência passada como a causa da ação presente: uma relação causal atuando através do tempo substitui a confiança que as narrativas mais antigas depositavam nos disfarces e nas coincidências, e isso tende a dar ao romance uma estrutura mais coesa." (WATT, 2010, p. 23)
} 


\section{4 - De volta ao medievo: intenção e acaso no percurso de Perceval}

A disjunção entre as intenções expressas por Perceval e os acontecimentos determinantes para seu destino, pode ser observada desde o princípio de sua história, naquele que será o fato decisivo para sua trajetória futura, o encontro com o grupo de cavaleiros que iriam despertar-lhe o irresistível desejo de tornar-se alguém como eles. No dia em que isso aconteceu, sua intenção expressa era, unicamente, a de ver o trabalho dos homens que cultivavam as terras de sua mãe.

Aqui, porém, a disjunção inicial permite-nos vislumbrar o momento mesmo em que uma espécie de intenção superior, de origem desconhecida, literalmente irrompeu na consciência do personagem e passou a dominar sua vontade. ${ }^{16}$ Determinada, como foi, pelo deslumbramento provocado pela visão dos cavaleiros e suas armas reluzindo ao sol da manhã, essa intenção remete desde sua origem a um lugar distinto ao de sua consciência, pois, antes mesmo de obter as respostas sobre os usos e os significados de todo o aparato utilizado por eles, o desejo de tornar-se um cavaleiro já havia tomado sua vontade de maneira absolutamente irresistível: "Quisera fosse eu agora/Assim luminoso e assim feito!" (TROYES, 1994, p. 689, v. 180-181) ${ }^{17}$

O caráter imprevisto desse encontro, assim como a força exercida pela visão dos cavaleiros, está em consonância com os demais fatos dispostos na continuidade da narrativa. Em primeiro lugar, o de que o completo desconhecimento de um personagem tão presente em seu mundo, o cavaleiro, devia-se a uma intenção deliberada de sua mãe, temerosa de que ele tivesse o mesmo destino de seu pai e de seus dois irmãos, mortos em decorrência de combates e de guerras de cavalaria. Seu pertencimento a uma linhagem de cavaleiros sugere, então, uma primeira hipótese de leitura do sentido possível para a origem de seu desejo, de todo modo, alheio à sua consciência pessoal: o de como este encontro, apesar de fortuito, fora determinado pela força de um destino inelutável e irrevogável, inscrito em sua própria natureza.

\footnotetext{
${ }^{16}$ Para melhor situar a comparação estabelecida, recordemos que no romance de Dostoiévski a intenção do personagem já aparece como um fato desde o início da narrativa, sendo sua origem um dos objetos centrais da investigação operada pela narrativa. Elemento, mais uma vez, fundamental para o estabelecimento das diferenças entre as duas.

17 "Car fusse je or autretex/Ensi luisanz et ensi fez".
} 
Os acontecimentos posteriores apenas confirmarão a hipótese de uma intenção originalmente exterior à consciência do personagem, determinando suas ações e conjugando-as com encontros aparentemente fortuitos. Mas acrescentarão, porém, um elemento particular a esta determinação advinda da linhagem, o de uma predestinação para o cumprimento de uma missão diretamente ligada ao destino coletivo. Assim, quando já avistava o castelo do rei Artur, para onde havia ido com a intenção de realizar seu desejo, ele encontra um cavaleiro que portava armas vermelhas, as quais ele passará a desejar desde esse instante, e com a mesma força de seu desejo anterior. ${ }^{18}$ Já $^{-}$ no interior da corte de Artur, e demonstrando uma vez mais sua ingenuidade e total desconhecimento do mundo da cavalaria, Perceval pedirá ao rei que o faça cavaleiro, mas colocará como condição que lhes sejam dadas as armas vermelhas daquele cavaleiro. Vendo que Artur não realizaria seu desejo imediatamente, sem nem mesmo descer do cavalo, o jovem deixa a sala bastante aborrecido e, neste momento, uma jovem a quem ele saudara de passagem sorri e diz, para todos da corte ouvirem, que ele será o melhor cavaleiro do mundo. O caráter de predestinação das palavras da jovem, assim como sua falta de razão aparente ${ }^{19}$, será reforçado ao sabermos que ela não ria há muitos anos e, por causa disso, era um costume do louco da corte, repetir as seguintes palavras: “Esta jovem não rirá/Até o dia em que puder ver/Aquele que da cavalaria/Terá total senhoria." (TROYES, 1994, p. 711, v. 1059-1062.). ${ }^{20}$

O vaticínio da jovem, confirmado pelo louco, fora feito contra todas as evidências. E é significativo que a estes dois personagens, representantes de um aspecto irracional da corte, irá opor-se de maneira violenta o senescal Keu, que agredirá ambos - o louco e a jovem - fato que irá suscitar uma promessa de vingança por parte de Perceval. Porém, contrariando todas as expectativas, nosso protagonista terá seu desejo inicial satisfeito, pois, ao deixar a corte encontrará o "Cavaleiro Vermelho", e de maneira totalmente inesperada, após receber um golpe de lança devido à insistência com que pedia suas armas, o atingirá mortalmente com um dardo que trazia consigo.

\footnotetext{
${ }^{18}$ É preciso observar que a origem, aparentemente desconhecida e inexplicável dos desejos manifestos por Perceval não significa, no plano da construção narrativa, que eles sejam gratuitos ou destituídos de sentido. Assim, a cor vermelha poderia ser lida, segundo Daniel Poirion, a partir de duas perspectivas: a da expressão do orgulho do cavaleiro e a da paixão do jovem protagonista (TROYES, 1994).

19 Observar que ela diz, para justificar seu vaticínio, que ele foi feito a partir de si mesma: Je pans et croi an mon coraige (Eu penso e creio em meu íntimo) (TROYES, 1994, p. 711, v. 1040).

20 "Ceste pucele ne rira/Jusque tant que ele verra/Celui que de chevalerie/Avra tote la seignorie."
} 
Imediatamente após a morte do cavaleiro, Perceval iniciará a retirada de suas armas. A comicidade da cena, que não escapará a Yvonet, um personagem da corte de Artur que assistira a tudo desde o princípio, chega a ser grotesca: com dificuldades para tirar o elmo e a espada de seu oponente, Perceval irrita-se e diz a Yonet que apenas retalhando o corpo do morto em várias partes, como se fosse prepará-las para assar na brasa, ele poderia arrancá-las, pois, não parecia haver distinção entre o dentro e o fora daquele cavaleiro $^{21}$. A comicidade da cena seguirá com a recusa de Perceval em retirar as roupas e as botas feitas por sua mãe, consentindo apenas em colocar sobre elas as esporas, a cota de malha e o elmo do cavaleiro vencido. É dessa maneira bizarra que ele montará, pela primeira vez, num cavalo dotado de estribos. Em sua concretude crua e cômica o episódio indica, portanto, a completa falta de noção de Perceval sobre o significado de ser um cavaleiro e, por consequência, a disjunção entre o impulso que o faz seguir adiante e a sua compreensão a respeito do sentido daquilo que está tentando vir a ser.

Esse desconhecimento de sua real condição e do significado de seus desejos revela-se, ainda, por Perceval acreditar ter sido transformado em cavaleiro pela simples utilização das armas, mesmo sem ter sido treinado para tal. Por esta razão, sua intenção consciente, a partir deste momento, é apenas a de retornar para a casa de sua mãe, para saber se ela estava bem, pois a viu desmaiar no momento de sua saída para a corte de Artur. ${ }^{22}$ E nesse retorno, novamente por casualidade, passará pelo castelo de um nobre chamado Goornemont de Goort onde, agora sim, receberá o treinamento necessário para combater como um cavaleiro e, ao fim dele, passará pelo ritual de entrada na cavalaria, o adubamento.

Durante o processo de treinamento, um comentário feito por Goornemont, admirado pela rapidez do aprendizado de Perceval, parece confirmar a hipótese, aventada anteriormente, de que a força para se tornar um cavaleiro inscrevia-se em sua própria natureza, necessitando apenas de um esforço corretamente dirigido, este sim ocorrido no nível de sua consciência.

\footnotetext{
${ }^{21}$ Vale à pena, por sua extraordinária força sugestiva, transcrever os versos: “(...) ce dedanz et ce defors/Est trestot un, si con moi sanble,/Qu'eles se tiennent si ansanble."; "(...) o dentro e o fora/são uma coisa só, assim me parece,/Pois elas encontram-se bem unidas." (TROYES, 1994, p. 713 , v. $1140-1142$ ).

${ }^{22}$ É verdade que a força deste desejo de reencontrar a mãe contrasta - e parece mesmo contradizer - com a aparente negligência de nosso heroi, ao não retornar para casa no momento em que a vira desmaiar. Mas esta oposição me parece apenas reforçar a força e o caráter exterior do impulso que o impelira a tornar-se um cavaleiro.
} 
Assim, para Goornemont, esta habilidade inata "(...) vinha de sua natureza;/E, quando a Natureza ensina/E o coração com ela se afina,/Nada pode lhe fazer agravo,/Pois Natureza e Coração fazem o trabalho." (TROYES, 1994, p. 722 , v. $1480-1484){ }^{23}$

Instado por este personagem, que adquire uma forte ascendência sobre ele, Perceval promete não mais citar sua mãe como referência de seus atos e pensamentos, além de concordar, finalmente, em substituir as roupas feitas por ela por outras mais apropriadas a sua nova condição de cavaleiro. Condição, a propósito, reconhecida pelo narrador, ao substituir o termo "valete" (vaslet), até então utilizado para referir-se a ele, pela expressão "o novo cavaleiro": "Li noviax chevaliers s'an part." (TROYES, 1994, p. 727, v. 1699).

A expressão é utilizada no verso inicial de um novo episódio, desencadeado após a recusa de Perceval em permanecer no castelo de Goornemont, pelo motivo já manifesto de retornar para sua casa e descobrir o que acontecera com sua mãe. Uma vez mais, porém, o acaso o conduzirá a uma experiência decisiva em sua formação, desta vez no castelo de Brancaflor, então senhora do castelo desde a morte de seu pai. Por causa dela, que estava prestes a ser entregue para um personagem chamado Clamadeu das Ilhas, por não ter mais forças para resistir ao assédio às suas terras -, ele irá combater este rei e, antes dele, seu senescal, Aguingerron. O triunfo no combate contra estes dois guerreiros e a ligação amorosa estabelecida a partir de então com Brancaflor assinalam, assim, o termo de sua formação como um perfeito cavaleiro, conforme a formulação do ideal de cavalaria nos demais romances de Chrétien de Troyes. ${ }^{24}$

Porém, diferentemente dos demais romances deste autor, a tensão dramática da narrativa não será mantida por algum tipo de obstáculo para a continuidade ou a consumação da relação amorosa. Assim, recusando os insistentes convites de Brancaflor e a própria possibilidade de tornar-se senhor de seu castelo e ali estabelecer-se em definitivo, ele fará uma nova partida.

\footnotetext{
23 “(...) venoit de Nature;/Et quant Nature li aprant/Et li cuers del tot i antant,/Ne li puet estre riens grevainne/La ou Nature et Cuers se painne."

${ }^{24}$ Esta conjunção entre as virtudes cavaleirescas e as virtudes do amor, onde este aparece como o elemento fundamental, é sintetizada no prólogo ao seu "O Cavaleiro do Leão": "(...) aqueles que sabiam amar/Podiam ser chamados de corteses/Audazes, generosos e honrados."; "(...) cil qui soloient amer/Se feisoent cortois clamer/Et preu et large et enorable." (TROYES, 1994, p. 339, v. 21-22; ed. Karl Uitti). No conjunto de uma enorme bibliografia, para uma visão introdutória à obra de Chrétien de Troyes: (FRAPPIER, 1957); (UITTI, 1995); (LACY e GRIMBERT, 2005). Uma definição sintética e esclarecedora da concepção de cortesia pode ser encontrada em: (ZUMTHOR, 1972, p. 550-560).
} 
Essa nova partida o levará, de maneira novamente inesperada, ao castelo do rei Pescador, onde ocorreriam as cenas diante das quais silenciou. E que, muito mais tarde, o levariam à confissão desesperada com que iniciamos este texto. ${ }^{25}$

\section{5 - Uma hipótese: a motivação está na forma?}

Até aqui utilizei a palavra acaso para designar o elemento disjuntivo entre a intenção expressa de Perceval e os encontros inesperados, porém, decisivos e necessários para sua formação. E vimos como, mesmo o desígnio formulado conscientemente por ele, o de tornar-se um cavaleiro, obedecia a determinações e a impulsos situados originalmente no exterior de sua consciência pessoal. ${ }^{26}$

Mas é preciso reiterar: o acaso, por si mesmo, não é, de modo algum, o elemento determinante para o estranhamento do leitor moderno, e sim o fato de ele conduzir Perceval na direção das experiências necessárias e imprescindíveis para a realização de seu destino. E, como nossa incursão no romance de Dostoiévski ressaltou pelo contraste, devido ao fato de não haver, por parte do narrador medieval e de seu personagem, nenhuma demonstração de estranheza com relação a este modo das coisas acontecerem. Estranhamento simétrico ao que sentimos quando constatamos as reações distintas de Perceval com relação às acusações similares de que ele havia sido objeto. Assim, uma questão que nos parecia estritamente ligada ao significado da narrativa, mostrou-se igualmente afeita à sua forma, e nela, talvez, encontrará sua solução.

Admitamos, novamente, que nosso incômodo com a função determinante do acaso e com a suposta incoerência das reações de Perceval, talvez seja, apenas, a expressão da impossibilidade de exprimir um elemento au-

\footnotetext{
${ }^{25}$ Não deve ter escapado ao leitor, ao acompanhar a deriva de Perceval entre os diferentes castelos outra aparente inconsistência narrativa, que novamente não pareceu incomodar ao seu narrador: se ele foi, sem problemas, de sua casa até a corte de Artur, porque agora ele parece vagar sem direção? Sem direção e, ao mesmo tempo, como notamos, sempre realizando encontros necessários. E não seria supérfluo, a este respeito, mencionar o estranho episódio da espada trazida por uma jovem ao rei Pescador, na mesma noite em que Perceval esteve no castelo. Uma espada com virtudes mágicas que teria sido forjada para um cavaleiro exemplar e que será, imediatamente, ofertada pelo rei ao jovem Perceval.

${ }^{26}$ Podemos dizer que estas determinações são de dois níveis, o primeiro dos quais, o seu pertencimento a uma linhagem de cavaleiros, ou seja, à sua "natureza", como observou Goornemont de Goort durante seu treinamento, ainda depende, para sua realização, de um esforço ligado à intenção, ao coração. O segundo nível de determinações, no entanto, aquele relacionado com a predestinação de Perceval, que o conduzirá finalmente ao castelo do rei Pescador, só pode encontrar-se, por definição, fora de qualquer âmbito ligado às escolhas conscientes do personagem.
} 
sente aos nossos olhos de leitores modernos. Em outras palavras, e reiterando o que já dissemos acima, este incômodo talvez exprima nossa dificuldade para apreender o modo próprio da narrativa medieval criar as conexões e os sentidos de sua trama, daí resultando a impressão de que estas não sejam suficientemente e razoavelmente explicitadas e explicadas.

Mas, se admitirmos que, ao contrário de Dostoiévski, Chrétien de Troyes não está investigando um destino, mas revelando o modo como ele realizou-se, tal incômodo deixa de existir ou, pelo menos, transfere-se para outro plano, o do incômodo em admitir a submissão da vontade individual a forças que lhes são exteriores. Essa admissão nos deixaria perceber que a impressão de inconsistência narrativa do Perceval decorre de uma forma de organização em que os episódios são entrelaçados como blocos individuais e quase autônomos, cuja função é menos a de estabelecer uma continuidade causal entre seus fatos do que a de assegurar o sentido do percurso de seu protagonista. Organização que não caracterizou apenas este romance de Chrétien de Troyes, conforme a descrição sintética de Douglas Kelly a respeito da articulação narrativa característica de suas narrativas:

The grail, like Guenevere, the Magic Fountain, Joy is a goal ${ }^{27}$. The goal is achieved, in most of Chrétien's narrative, by a quest. The quest motif implies a series of displacements interspersed episodically with aventures. The aventure usually appears fortuitous, although it may have an at first hidden rationale or cause which becomes explicit in the course of the adventure or at some later point in the narrative. The movement from beginning of quest to achievement of the goal fixes a narrative beginning and end. The middle, structurally a fixed midpoint of major significance for the san, connects multiple and diverse adventures and episodes that reveal the qualities of the questing knight and his lady. The focus on the goal of the quest thus gives the narrative a beginning, middle and end. (KELLY, 1985, p. 36-37)28.

Desse modo, a inexistência de explicação ou de perplexidade para com relação ao acaso ou a incoerência das reações do personagem, não deveria ser interpretada como resultado de alguma inconsistência narrativa, mas, ao

\footnotetext{
${ }^{27}$ Guenevere, Magic Fountain e Joy são referências a motivos narrativos dos seguintes romances de Chrétien de Troyes: Lancelot, ou O Cavaleiro da Charrete, Yvain, ou O Cavaleiro do Leão e Erec e Enide.

${ }^{28}$ Também: "The juxtaposicion of episodes within the overarching quests of romance narrative does not require but may occasionaly use the logic of causation. In general, episodic construction in romance is disjunctive, reiterative, not organic. It follows the non-mimetic logic of design, which builds the narrative structure through echoes and conventions constantly reinvented." (BRUCKNER, 2000, p. 27).
} 
contrário, da consideração de que os fatos narrados por ela obedecem a outra lógica, destinada a expor uma verdade inicialmente oculta para aquele que a buscava. Ciente deste objetivo narrativo, o intérprete do Perceval é conduzido menos a uma investigação, reiteremos o fato, do que a uma revelação, onde a ordem dos fatos é dirigida, fundamentalmente, pela necessidade da ocorrência de certos eventos. Situada nessa perspectiva, a razão para as diferentes reações de Perceval em face das acusações feitas a ele deveria ser buscada através da indicação, dada pela disposição dos episódios da narrativa, dos estágios de realização daquele desígnio revelador do sentido geral de sua aventura.

Nesse sentido, se a chegada de Perceval ao castelo do rei Pescador ocorreu em seguida à consumação de sua formação como cavaleiro, seu involuntário - se é que se pode usar este termo - fracasso ao silenciar diante do graal deve ser visto a partir desse fato. E, sua posterior integração à corte de Artur como o termo deste processo, na medida em que desde seu princípio ele havia sido orientado para isso. A respeito disso, não se deveria esquecer, muito pelo contrário, que entre a acusação da prima e a da jovem disforme, dois episódios parecem selar a consumação de Perceval como um cavaleiro perfeito: a oportunidade de redimir-se de um erro cometido logo após a saída da casa de sua mãe quando, depois de invadir a tenda de uma jovem, forçou-a a beijá-lo, tirou seu anel e comeu de sua comida, fato que despertaria o ciúme de seu amante. Este punirá duramente a jovem e somente o combate com o próprio Perceval, ocorrido logo após ele deixar sua prima, fará com que ele suspenda as penas a que havia submetido à jovem. Em seguida, a visão de algumas gotas de sangue na neve - deixadas por uma gansa atacada por um falcão - o fará recordar o rosto de Brancaflor e, por ele, mergulhar num estado de profunda contemplação e absorção, de que apenas sairá para enfrentar e derrotar dois cavaleiros de Artur que tentaram despertá-lo à força. Um deles era justamente Keu, o senescal do reino, de quem ele prometera vingar a agressão da jovem que lhe previu o futuro de melhor cavaleiro do mundo, ainda em sua primeira passagem pela corte de Artur. Episódio que, a um só tempo, confirma a previsão feita pela jovem e assinala a entrada do jovem no círculo dos amantes, reiterando assim a conjunção entre as virtudes do amor e as das armas. Processo, no entanto, marcado por uma falha, por uma incompletude, em que pese ele ter realizado e cumprido adequadamente tudo que se esperava de um perfeito cavaleiro.

$$
* * *
$$


A interrogação sobre as razões da tomada de consciência de Perceval ter ocorrido apenas no momento da segunda acusação, no momento em que se celebrava a confirmação de seu destino glorioso deve ser colocada, então, no contexto da lógica subjacente à organização da narrativa de Chrétien de Troyes, fundada, como vimos numa espécie de desenho onde a superposição de suas peças constitutivas obedece não, pelo menos prioritariamente, às exigências de uma lógica causal, mas ao sentido geral que se quer impor a ela. ${ }^{29}$

Desse modo, e apesar do caráter inconcluso da narrativa, a aparente incoerência das reações distintas de Perceval, assim como as ausências de explicações por parte do narrador, torna-se não apenas inteiramente coerente com a organização narrativa como, também, reveladora de um sentido essencial em sua formulação: a despeito de Perceval ter realizado, em sua plenitude, o ideal cortês de união das virtudes cavaleirescas e amorosas, seu silêncio diante do cortejo do graal revelou uma incompletude essencial em sua formação, apenas passível de superação pelo duplo ato regenerador da confissão e da comunhão. A assimilação desta falta em sua consciência, ocorrida justamente no momento em que se consumava sua realização como um perfeito cavaleiro cortês, introduzia, portanto, um elemento ausente no ideal cortês dos demais romances de Chrétien de Troyes, onde a mácula de um pecado originário não era um fator impeditivo para essa realização. Coerência narrativa consumada quando se percebe a situação paradoxal armada pela narrativa no momento culminante de sua confissão: ele jamais teria chegado ao castelo do rei Pescador se não tivesse abandonado a casa de sua mãe para tornar-se um cavaleiro, porém, esse "pecado" teria sido

\footnotetext{
${ }^{29}$ Daí, por exemplo, a subordinação dos imperativos da vida cotidiana nas "aventuras improváveis" de seus heróis, para retomar as palavras de Peter Gay acerca do romance realista do século XIX (ver nota 12): é suficiente, para o narrador do Perceval e, por extensão, para o seu auditório, narrar os episódios necessários para a compreensão do processo de formação de seu protagonista, pois, não se espera que ele explique suas condições de possibilidade. Este desinteresse não significa, por outro lado, o absoluto desprezo pelas necessidades básicas humanas, o que é demonstrado pela própria motivação que leva Perceval a pedir abrigo nos diferentes castelos encontrados ao longo de seu percurso. Em resumo, as necessidades materiais estavam subentendidas, mesmo quando suprimidas da narração. Aqui, a comparação poderá novamente nos auxiliar, agora com uma passagem do Quixote, aquela em que o dono de uma venda, onde o "Cavaleiro da Triste Figura" hospedou-se em sua primeira saída, esclareceu-lhe sobre a necessidade de atender as necessidades materiais, as quais Quixote desprezava por não serem mencionadas nos romances que moviam sua imaginação: "A esto dijo el ventero que se engañaba, que, puesto caso que en las historias no se escribia, por haberles parecido a los autores de ellas que no era menester escribir una cosa tan clara y tan necessaria de traer-se como eran dineros y camisas limpias (...)" (CERVANTES, 2004, p. 42-43, grifo meu).
} 
a causa, já vimos antes, de seu silêncio diante do cortejo do graal. Atravessando o arco temporal da formação de Perceval como o perfeito cavaleiro, a imagem fixada por este paradoxo somente será desfeita pelo ato purificador de sua confissão e de sua comunhão, submetendo então a cavalaria ao poder superior dos sacramentos. O que deveria nos fazer ver, enfim, a consonância entre este deslocamento e as correntes sociais e culturais contemporâneas à composição de Chrétien de Troyes, orientadas para uma crescente subordinação dos laicos às orientações clericais, movimento estreitamente ligado à interiorização dos preceitos clericais, sendo esta estimulada, justamente, através da ênfase penitencial na confissão auricular. ${ }^{30}$

\section{6 - As relações entre a forma, o sentido e as concepções de pessoa}

Retornemos, enfim, ao que nos pareceu de início um problema de inconsistência narrativa no Perceval de Chrétien de Troyes: as reações distintas de seu protagonista às duas acusações semelhantes, sem que nenhum dado narrativo as justificasse de maneira inteiramente convincente. Impressão logo associada ao incômodo, pelo que nos parecera uma inexplicável omissão de seu narrador, com relação àquelas reações aparentemente contraditórias.

Em seguida, para estabelecer a perspectiva a partir da qual partiram tanto a impressão como o incômodo, fizemos uma incursão pelo romance realista moderno. $\mathrm{O}$ contraste proporcionado por essa incursão revelou os dois aspectos sobre os quais assentavam os pressupostos da impressão e do incômodo iniciais: aqueles relacionados com a percepção de uma disjunção entre a motivação dos personagens - indeterminada ou exterior à sua vontade - e o caráter decisivo das ações decorrentes destas em seu destino; e, aqui, o efeito de contraste resultante da comparação revelou-se na sua

\footnotetext{
${ }^{30}$ Subscrevo, a este respeito, a avaliação de J. Baschet a respeito das mudanças penitenciais do período e suas relações com o desenvolvimento da devoção pessoal entre os laicos: "Por vezes, evoca-se, a propósito desses fenômenos, uma "promoção dos laicos" no seio da Igreja. Mas trata-se antes da adoção pelos laicos de práticas religiosas anteriormente reservadas aos clérigos. A consequência disso é a sua submissão ainda mais estrita aos valores e às normas elaboradas pela Igreja, sobretudo porque os clérigos não renunciaram então a nenhum de seus privilégios essenciais em matéria de intercessão sacramental e a dominação ideológica da instituição eclesial parece mais absoluta do que nunca. Se há "promoção dos laicos", esta expressão só pode significar uma maior difusão, no corpo social, das normas clericais, uma melhor interiorização destas pelos laicos, que os conduz a participar mais ativamente da reprodução de um sistema eclesial dominado pelo clero." (BASCHET, 2006, p. 221).
} 
plenitude, através do tratamento distinto conferido por um e outro narrador a esta disjunção. Assim, enquanto a combinação entre a indeterminação da origem dos atos do personagem e o efeito imprevisto, porém, determinante, dos fatos desencadeados por eles mostrou-se crucial e problemática para o narrador moderno, para o narrador medieval ela aparece como o próprio tecido constitutivo de sua trama narrativa, a qual parece relegar a um plano secundário os mecanismos da causalidade e da intenção consciente.

Mas a simples constatação da diferença e da singularidade do texto medieval não resolve, no entanto, uma questão por ela própria aberta, essencialmente histórica: a de sua inserção no interior de uma configuração cultural particular, capaz de restituir a normalidade plena daquilo que a princípio nos parecia estranho e deslocado.

Para fazer isso voltemos, portanto, ao lugar a que fomos conduzidos pelo estranhamento inicial relativo à disposição de certos atos de Perceval: a constatação de um padrão de organização narrativa, de determinação das ações do personagem e de disposição dos acontecimentos, alheia e indiferente aos princípios de verossimilhança da narrativa moderna. Sendo esta ancorada num desejo de reproduzir, nas formas próprias da representação ficcional, o modo de funcionamento do chamado mundo real e, nele, o da pessoa humana, não se deveria buscar aí, numa possível concepção distinta de ambos, do real e da pessoa, a raiz dos estranhamentos que nos conduziram por este ensaio de compreensão de um modo narrativo de outro tempo?

$$
* * *
$$

A resposta a essa pergunta pressupõe uma incursão, ainda que necessariamente não exaustiva, dados os limites deste texto, através dos caminhos que levaram alguns medievalistas a colocar as concepções sobre a pessoa como objeto de investigação. ${ }^{31}$ Incursão que nos levará, inicialmente, para o interior do debate historiográfico, já não tão recente, acerca da suposta "descoberta" ou "nascimento" do indivíduo durante a Idade Média, mais preci-

\footnotetext{
${ }^{31}$ A concepção de pessoa na Idade Média foi objeto de uma síntese recente, instigante e esclarecedora, elaborada por Jerôme Baschet, para a qual ainda voltarei. Por ora, remeto para a importância atribuída por este autor sobre as implicações mais profundas dessa temática, as quais situam as relações aqui propostas em seu contexto mais amplo: "São incontáveis os trabalhos antropológicos que demonstram que as concepções de pessoa constituem uma das dimensões mais profundas dos sistemas de representações e que estão estreitamente imbricadas na lógica de conjunto da sociedade de que são parte integrante." (BASCHET, 2019, p. 10).
} 
samente, no decorrer do século XII. ${ }^{32}$ Parte de uma dinâmica historiográfica mais ampla, que tendeu a recuar para o período medieval desenvolvimentos históricos anteriormente atribuídos aos séculos posteriores, alguns de seus elementos foram antecipados por outros autores, mas caberia ao historiador americano Colin Morris reuni-los de maneira coerente e abrangente em seu livro, muito apropriadamente intitulado, "The Discovery of the Individual", publicado originalmente no ano de $1972 .{ }^{33}$

Neste livro, através de uma brilhante argumentação e de uma variada documentação, Morris defendia a tese de que a concepção do ser humano como uma entidade autônoma, definida por uma intransferível singularidade, interior e exterior - característica da moderna sociedade ocidental -, teria tido sua origem no decorrer do século XII. As narrativas de Chrétien de Troyes situadas em um capítulo intitulado "The Individual and Society" eram, justamente, um dos testemunhos invocados por Morris para fundamentar sua tese (MORRIS, 1987). Segundo ele, as narrativas de Chrétien de Troyes refletiriam a necessidade urgente de uma reflexão ética sobre as ocupações sociais, pois, as inúmeras transformações culturais, econômicas e políticas em curso, além de propiciarem maior amplitude de escolha aos indivíduos, estimulava-os a colocar em questão aquelas mais tradicionais.

Visto dessa perspectiva, o percurso de Perceval deveria ser lido como uma tentativa de encontrar seu "verdadeiro eu" (true self), através de uma busca intimamente ligada com "(...) his deepening understanding of what it means to be a knight." E, nessa busca, era essencial "(...) the voluntary action of the heroes." (MORRIS, 1987, p. 136-137, grifo meu). Note-se, aqui, a relação estabelecida entre a ação voluntária e a descoberta de si, pois, através dela

\footnotetext{
32 Seria importante, aqui, observar as considerações de Louis Dumont sobre os dois sentidos do termo "indivíduo": em sua acepção empírica, ele designa simplesmente a entidade humana particular e em sua acepção valorativa, própria do "individualismo" da Modernidade ocidental, onde aquela entidade particular é vista como um "ser moral autônomo" (DUMONT, 1991, p. 37), “(...) fonte de suas representações e de seus atos, seu fundamento(...)” (RENAULT, 1998, p. 10). É, portanto, com relação às origens do indivíduo em sua segunda acepção que se refere o debate historiográfico em questão.

${ }^{33}$ Um evento crucial neste movimento foi a publicação, no ano de 1927, do livro "The Renaissance of the Twelfth Century, do também americano Charles Homer Haskins. A tese de Haskins será fundamental para a construção dos argumentos de Morris, pois, para este historiador, a redescoberta das letras clássicas teria sido um dos fatores fundamentais para a expressão e a percepção da consciência de si. E, não deixa de ser significativo constatar que Jacob Burckhardt, em seu livro clássico sobre o Renascimento, dedicara uma de suas partes ao "desenvolvimento do indivíduo", visto como um dos elementos de ruptura entre o Renascimento e a Idade Média (BURCKHARDT, 1991, p. 81-103).
} 
pode-se apreender exatamente o que Morris julgava encontrar na Idade Média. Seria interessante, também, para situar a perspectiva a partir da qual ele olhava para estes textos, retomar as palavras em que ele exprimia, nas páginas iniciais de seu livro, sua concepção de indivíduo: "Whatever ties of love or loyalty may bind us to other people, we are aware that there is an inner being of our own; that we are individuals." (MORRIS, 1972, p. 1, grifos meus).

Alguns anos depois da publicação do livro de Morris, um artigo da medievalista americana Caroline Bynum apresentaria uma visão substancialmente distinta acerca da questão. Assim, apesar de concordar quanto ao fato de as evidências analisadas por Morris apontarem, inegavelmente, para a existência de um maior interesse a respeito do "si mesmo" (self), suas conclusões iriam contrapor-se frontalmente à tese de que o indivíduo teria sido "descoberto" no século XII. Em primeiro lugar, sua análise do corpus textual produzido pelos monges e cônegos regulares daquele século evidenciava que este interesse pelo self não excluía, muito pelo contrário, um “(...) quite self-conscious interest in the process of belonging to groups and filling roles" (BYNUM, 1982, p. 85). Ela mostrava, enfim, como a maior amplitude de escolhas oferecidas ao indivíduo subordinava-se à necessidade, incontornável para a "descoberta de si mesmo", de pertencer a estes grupos e, em seu interior, seguir os modelos e os caminhos estabelecidos por eles. Nessa perspectiva, ao invés de um "aprofundamento pessoal de sua compreensão da cavalaria", como afirmava Morris, Perceval ofereceria um modelo ideal a ser seguido pelos cavaleiros de seu tempo. Leitura, de resto, em consonância com a hipótese, sugerida acima, para explicar o arrependimento tardio de Perceval onde, recordemos, sua gloriosa entronização na corte de Artur coincidiria com a revelação de sua trágica omissão diante do Graal, a qual somente seria redimida por sua posterior subordinação às orientações clericais, por ocasião de seu encontro com o eremita.

Ainda mais significativa, para a compreensão das relações entre a leitura que aqui propomos para este episódio e as questões relativas ao estatuto da pessoa na Idade Média, é a sua discordância com relação ao significado da expressão "descoberta de si mesmo", utilizada por Morris no sentido moderno, o de descoberta de uma personalidade singular e intransferível: “(...) the twelfth century regarded the discovery of homo interior, or seipsum, as the 
discovery within oneself of human nature made in the image of God - an imago Dei that is the same for all human beings." (BYNUM, 1982, p. 87) ${ }^{34}$

No ano de 1989, um artigo publicado pelo medievalista francês Jean-Claude Schmitt iria operar um deslocamento substancial neste debate, ao classificar como uma "ficção historiográfica" o que ele definiu, de maneira provocativa, como a "gesta do individualismo", cujos ritmos fortes "(...) estranhamente coincidem com as grandes 'viradas' que o recorte universitário do tempo histórico prima em assinalar." (SCHMITT, 2014, p. 215). Portanto, ao invés de buscar, na Idade Média, a origem de um desenvolvimento histórico posterior, ele propunha, através do exame da noção de pessoa, a identificação de uma configuração específica e de sua dinâmica tendencial ao longo daquele período. Bastante presente no universo conceitual do cristianismo medieval - ao contrário do termo "indivíduo", pelo menos no sentido conferido a ele pela Modernidade - o exame das “(...) contradições da noção de pessoa [revelaria] o contexto conceitual de uma tendência, incessantemente contrariada, à individuação." (SCHMITT, 2014, p. 215). Ao definir o sentido medieval deste processo, suas conclusões não seriam muito diferentes daquelas de Caroline Bynum: “(...) muito mais do que exaltar a consciência individual, ela tende a abolir o sujeito na divindade da qual ele é a imagem e na humanidade da qual compartilha o destino." (SCHMITT, 2014, p. 233).

Os efeitos historiográficos do deslocamento proposto pelo artigo de Jean-Claude Schmitt podem ser observados, de maneira bastante evidente, no espaço dedicado à noção de pessoa por Jerôme Baschet, em sua já mencionada síntese do período medieval, onde ela ocupa todo um capítulo da segunda parte de seu livro, aquela dedicada às "estruturas fundamentais da sociedade medieval". ${ }^{35}$

Mais recentemente, este mesmo historiador retomaria o tema de maneira muito mais ampla, em seu livro "Corpos e almas: uma história da pessoa na Idade Média" (BASCHET, 2019) ${ }^{36}$, estruturado a partir de duas teses com-

\footnotetext{
${ }^{34}$ Observe-se que, aqui, Caroline Bynum está seguindo uma correção proposta por John Benton ao livro de Colin Morris, em texto escrito sobre a mesma questão (BENTON, 1991). Este autor, no entanto, afasta-se de Bynum ao supor, mesmo de maneira implícita, que os processos de interiorização só poderiam ser plenamente realizados no contexto da moderna configuração de pessoa. Note-se, por significativo para a aproximação entre o livro de Morris e o de Haskins, que o texto de Benton originou-se de um conjunto de conferências organizado para celebrar o aparecimento do livro de Charles Haskins sobre o renascimento do século XII.

${ }^{35}$ Refiro-me ao capítulo IV da segunda parte deste livro, intitulado "Corpos e almas: pessoa humana e sociedade cristã" (BASCHET, 2006, p. 409-445)

${ }^{36}$ Para a exposição seguinte ver: (BASCHET, 2019, p. 20-58)
} 
plementares, e contrárias ao lugar comum de ter sido o período medieval o momento de estabelecimento de um dos traços constituintes do Ocidente, o da estrita separação e oposição entre o corpo e a mente, ou, nos termos do período em questão, entre o corpo e a alma. Segundo ele, a Idade Média teria conhecido uma "dualidade não dualista" marcada, inclusive, pela afirmação crescente de uma "dinâmica antidualista". Nessa perspectiva, a dualidade entre o corpo e a alma tenderia a resolver-se no ideal de uma concepção harmônica e interativa de suas relações, consoante com o papel cada vez mais decisivo desempenhado pela Igreja na estruturação da ordem social. Dinâmica que iria culminar com a vigorosa afirmação de Tomás de Aquino acerca da plenitude do ser humano, apenas realizada através da unidade entre essas duas entidades. E, enfim, na concepção de um "corpo glorioso", ressuscitado com o vigor e a potência de sua materialidade, porém, liberto das necessidades sexuais e alimentares que o constrangiam em sua estada terrestre.

Da exposição feita por Baschet acerca dos traços constituintes da pessoa medieval interessa-nos, particularmente, a aplicação feita por ele da noção de "pessoa relacional", a qual deve ser pensada como aquela "(...) que não pode ser concebida como um ponto - o 'eu' ocidental, definido em e por ele mesmo - mas, muito antes, como um microcosmo de relações." (BASCHET, 2019, p. 16-17). ${ }^{37}$ Desse modo, as duas entidades constituintes da pessoa, o corpo e a alma, seriam o resultado de uma rede de determinações exteriores a anteriores, porém, decisivas para sua constituição: enquanto a concepção do corpo era atribuída aos pais, em meio à teses distintas sobre a origem das almas, a tendência do pensamento medieval a este respeito foi a de privilegiar o "criacionismo", segundo o qual a alma de cada ser humano era criada por Deus e por ele infundida no embrião. ${ }^{38}$

\footnotetext{
${ }^{37}$ Baschet cita, como fonte dessa concepção de "pessoa relacional", os estudos da antropóloga Marilyn Strathern. (BASCHET, 2019, p. 15-16).

${ }^{38}$ Observe-se, porém, que o "criacionismo", ao atribuir a cada ser humano singular uma alma poderia "(...) ser interpretado, como o sinal de uma afirmação do caráter individual da pessoa cristã" (BASCHET, 2019, p. 38), fato que introduz uma certa ambiguidade na questão. E que, por essa razão, revela o que se ganha ao situar a situar o desenvolvimento que nos levou à tentativa de compreender a noção de pessoa medieval no interior do debate historiográfico sobre as supostas origens, igualmente medievais, do indivíduo moderno. O que estamos chamando de ambiguidade poderia ser, também, deslocado para outro campo de interrogações, tangencial ao nosso texto, porém, vital para a compreensão de algumas questões contemporâneas e para dimensionarmos a importância dos estudos medievais neste contexto. Trata-se, aqui, da interrogação sobre as possíveis singularidades ocidentais, uma delas sendo justamente sua noção de pessoa, objeto dos dois últimos capítulos do livro de Baschet. Nessa perspectiva, não se trataria
} 
Note-se, ainda, que embora singularizada por sua associação com um ser humano particular, não se deveria ver a noção de alma como simples expressão medieval da ideia moderna de "eu" ou de "si mesmo", ou seja, como o centro autônomo e distinto de todos os demais, característico do individualismo moderno, pois, por sua própria origem, ela implicava na existência de uma dimensão excêntrica à da consciência pessoal. Dimensão plenamente perceptível na concepção, difusa em todo o pensamento medieval, de que a infusão da alma nos seres humanos propiciava a cada indivíduo particular a realização da imagem divina, desde que seu percurso de vida permitisse-lhe restaurar a semelhança perdida por ocasião do pecado original, o que termina por nos reenviar para as observações de Caroline Bynum e de Jean-Claude Schmitt sobre a natureza paradoxal desse percurso, apenas possível quando o indivíduo "perdia-se de si mesmo".

Ainda que não se deva conceber a narrativa romanesca como uma expressão simples e inequívoca do pensamento teológico, o pertencimento de ambos os discursos a uma configuração cultural comum sugere a existência de inevitáveis trânsitos e relações entre ambos. Assim, acredito que a dualidade relacional esboçada por Baschet poderia ser colocada em simetria à que identificamos ao observar as determinações exteriores do percurso de Perceval, as quais poderiam ser situadas em dois níveis, complementares, porém, hierárquicos: em primeiro lugar, o de seu pertencimento a uma determinada linhagem de cavaleiros, responsável pela irresistível pulsão que o levará para a cavalaria; depois, o da cadeia de eventos destituídos de causalidade aparente e desencadeados por atos cujas motivações originais não tinham a intenção de conduzi-lo ao castelo do Graal e, portanto, de fazê-lo defrontar-se com a incompletude de sua condição, se destituída da elevação apenas obtida através do contato com o sagrado clerical.

de identificar as duas concepções de pessoa, mas de interrogar-se sobre os elementos contidos na concepção medieval passíveis de uma evolução posterior na direção do "individualismo". Observe-se, enfim, que essa interrogação constitui o eixo de um estudo que não poderia ser aqui omitido, quando se pensa na inspiração que ele trouxe para a perspectiva adotada não apenas por Baschet mas, também, por Schmitt e por Dumont. Refiro-me, obviamente, à conferência de Marcel Mauss acerca da forma como a noção de pessoa teria sido lentamente elaborada, ao longo do tempo e do espaço, até adquirir, na Europa do final do século XVIII, a noção de "eu". (MAUSS, 2003). Sintetizado dessa forma, o estudo de Mauss parece, de maneira inequívoca, responder de maneira evolucionista à questão, porém, como bem observou Baschet, sua exposição contém uma boa dose de ambiguidade, refletida na interpretação divergente que ela veio a suscitar entre seus discípulos, onde aquele "eu" tendeu a ser visto como a plena realização da pessoa ou, apenas, como uma de suas formas possíveis. (BASCHET, 2019). 
Quando situamos, enfim, nosso personagem no centro dessa rede de relações e de determinações exteriores e anteriores à sua constituição individual, deixa de parecer-nos inverossímil ou inconsistente a maneira como este percurso foi relatado por seu narrador. Este relato, muito pelo contrário, mostra-se perfeitamente ajustado às concepções de pessoa de seu tempo, ao ser movido pela subordinação das motivações pessoais - sendo estas entendidas como aquelas originadas na dimensão consciente de seu agente - a uma cadeia de eventos destituídos de elementos causais, porém, decisivos para o destino de seu personagem.

$$
* * *
$$

Assim, ainda que limitada ao lugar de uma conclusão aberta a investigações e desenvolvimentos posteriores, acredito haver no termo deste outro percurso, o da investigação aqui desenvolvida, uma sugestão, quase imperativa, de relacionar a forma e o sentido do Perceval a uma determinada concepção de pessoa humana e de seu lugar no mundo. E a interrogar, enfim, se o estranhamento moderno diante dos silêncios do narrador medieval não se deveria justamente à perda de contato com um tipo de experiência apenas possível no interior de um universo ordenado e submetido aos desígnios divinos, onde não seria estranho, por conseguinte, a existência de um fluxo ou de uma força orientada para um sentido preciso e estabelecendo um elo entre a intenção individual e o acontecimento, por mais que estes não fossem plasmados e percebidos em um nível imediatamente reconhecido pela consciência de seu agente.

O narrador de Dostoiévski, em contrapartida, movia-se num contexto cultural em que a existência de um centro de inteligência exterior ao indivíduo deixara de existir ou, simplesmente, tornara-se excessivamente incômodo e ameaçador para um sujeito centrado sobre si mesmo. Um contexto em que a concepção de indivíduo como um ser autônomo não permitiria, a não ser sob a luz de uma análise necessariamente aberta à consideração dos pressentimentos e das predestinações, admitir a estranha ligação entre os impulsos profundos da consciência pessoal e as ações desencadeadas independentemente de sua vontade.

Aqui, porém, estamos no limiar de outro desenvolvimento, apenas levemente tocado por este texto, ainda que se constitua como um horizonte contínuo que lhe permitiu e lhe forneceu, talvez, o essencial de seu roteiro e de suas reflexões. Um desenvolvimento no qual o romancista russo apareceria não como um exemplar da inquietação moderna acerca das aberturas 
exteriores do sujeito, mas como o precursor de uma longa linhagem de exploradores das profundezas possíveis de serem vislumbradas através destes deslizamentos da consciência pessoal.

O romance de Dostoiévski, neste sentido, não deveria ser visto apenas como um exemplar do romance realista do século XIX, mas como um dos sinais antecipadores de uma crítica futura, e cada vez mais presente na civilização ocidental, da concepção de pessoa autorreferencial e fundada unicamente em sua interioridade pessoal. O próprio livro de Jerôme Baschet me parece um exemplo significativo dessa tendência, ao apresentar como sua "dimensão central" a tentativa de encontrar os possíveis caminhos de superação da concepção de pessoa instituída pela Modernidade: "Trata-se de trabalhar para desfazer o núcleo duro - a concepção da pessoa autofundada e a-relacional, a superioridade, em valor, do indivíduo na relação com o coletivo - graças à afirmação decidida de uma concepção verdadeiramente relacional de pessoa." (BASCHET, 2019, p. 288).

Desenvolvimento que termina, então, por nos aproximar, de maneira imprevista, do universo medieval. Não, porém, movidos pelo anseio de nele reproduzir a própria imagem, mas pelo desejo de vislumbrar outras possibilidades de ser e de estar no mundo. E não residiria nesta busca um dos aspectos mais fascinantes da investigação histórica e, ao mesmo tempo, da necessidade imperiosa de sua existência?

\section{Referências Bibliográficas}

BASCHET, Jerôme. A Civilização Feudal: do ano mil à colonização da América. Tradução de Marcelo Rede. São Paulo: Globo, 2006.

BASCHET, Jerôme. Corpos e almas: uma História da pessoa na Idade Média. São Leopoldo: Editora Unisinos, 2019.

BENTON, John. Consciouness of Self and Perceptions of Individuality. In: BENSON, Robert e CONSTABLE, Giles. Renaissance and Renewal in The Twelfth Century. Toronto: University of Toronto Press, 1991, p. 263-295.

BRUCKNER, Matilda Tomaryn. The shape of romance in medieval France. In: KRUEGER, Roberta L. (Ed.) The Cambridge Companion to Medieval Romance. Cambridge: Cambridge Medieval Press, 2000.

BURCKHARDT, Jacob. A cultura do Renascimento na Itália. Tradução de Vera Lúcia de Oliveira Sarmento e Fernando de Azevedo Corrêa. Brasília: Editora da UNB, 1991.

BYNUM, Caroline. Did the Twelfth Century Discover the Individual?. In: Jesus as Mother: Studies in the Spirituality of the High Middle Ages. Berkeley/Los Angeles/London: University of California Press, 1982.

CERVANTES, Miguel. Don Quixote de la Mancha. Madri: Real Academia Española y Associación de Academias de la Lengua Espanõla, 2004. 
DELUMEAU, Jean. A confissão e o pecado. Tradução de Paulo Neves. São Paulo: Companhia das Letras, 1991.

DOSTOIÉVSKI, Fiódor. Crime e Castigo. Tradução de Paulo Bezerra. São Paulo: Editora 34, 2001.

DUMONT, Louis. Essais sur l'individualisme: Une perspective anthropologique sur l'idéologie modern. Paris: Éditions du Séuil, 1991.

FRAPPIER, Jean. Chrétien de Troyes. Paris: Hatier-Boivin, 1957.

GAY, Peter. Represálias Selvagens. Tradução de Rosaura Eichenberg. São Paulo: Companhia das Letras, 2010.

KELLY, Douglas. Chrétien de Troyes: The Narrator and His Art. Idem (org.) The Romances of Chrétien de Troyes: A Symposium. Lexington: French Forum, 1985, p. 13-47.

LACY, Norris J.; GRIMBERT, Joan Tasker. A Companion To Chrétien de Troyes. Cambridge: D. S. Brewer, 2005.

MAUSS, Marcel. Uma categoria do espírito humano: a noção de pessoa, a de "eu". In: Sociologia e Antropologia. Tradução de Paulo Neves. São Paulo: Cossac \& Naif, 2003, p. 367-397.

MORRIS, Colin. The Discovery of the Individual: 1050-1200. Toronto: University of Toronto Press, 1987.

RENAUT, Alain. $O$ indivíduo: reflexão acerca da filosofia do sujeito. Tradução de Elena Gaidano, Rio de Janeiro: Difel, 1998.

SCHMITT, Jean-Claude. A "descoberta do indivíduo": uma ficção historiográfica? In: O corpo, os ritos, os sonhos, o tempo. Tradução de Maria Ferreira. Petrópolis: Vozes, 2014, p. 215-233.

TROYES, Chrétien. Le Roman de Perceval ou Le Livre du Graal. Tübingem: Max Niemeyer Verlag, 1993.

TROYES, Chrétien de. CEuvres Complètes. Paris: Gallimard, 1994.

UITTI, Karl David. Chrétien de Troyes Revisited. New York: Twaine Publishers, 1995.

WATT, Ian. A Ascensão do Romance. Tradução de Hildegard Feist. São Paulo: Companhia das Letras, 2010.

ZUMTHOR, Paul. Essai de poétique médiévale. Paris: Seuil, 1972.

Recebido: 08/06/2020 - Aprovado: 15/03/2021

Editores Responsáveis

Júlio Pimentel Pinto e Flavio de Campos 